\title{
Attachment Patterns, Mourning Reactions, and Dysfunctional Romantic Relationship Beliefs among Young Adults with and without Early Parental Loss
}

\author{
Ali Varol ${ }^{a}$, Deniz Albayrak-Kaymak ${ }^{\text {b }}$, Sibel Akmehmet-Şekerler \\ and Marc A. Markell ${ }^{\text {d }}$
}

\begin{abstract}
The attachment patterns, mourning reactions and dysfunctional romantic relationship beliefs of young adults were examined in relation to early parental loss experience. Participants included 423 students at a public university in İstanbul. An online survey package was used in data collection. Analyses indicated no attachment pattern difference by loss status. For the early parental loss group, the dismissing attachment pattern and dysfunctional romantic relationship beliefs; and for the no loss group, preoccupied attachment pattern and dysunctional romantic relationship beliefs had positive relations. Participants with dismissing attachment patterns and high levels of mourning had more dysfunctional romantic relationship beliefs. Behavioral and physical types were the most; emotional and cognitive types were the least common mourning reactions.
\end{abstract}

Article info

Received: 03.05.2021

Revised: 30.07.2021

Accepted: 21.08.2021

Published online: 15.09.2021

Keywords: Early parental loss, young adults, attachment patterns, mourning reactions, dysfunctional romantic relationship beliefs

\section{Introduction}

Although the definition of life includes death, most of us live denying our mortality. Coming to terms with one's death requires maturity. Regardless of one's level of maturity, nevertheless, death of a loved one is always difficult to experience and accept. Witnessing death is painful because it is irrecoverable. The witness feels helpless and completely impotent while facing death. Feelings regarding the death of a loved one is "unmatched for its emptiness and profound sadness" (Kübler-Ross et al., 2014, p. 29). Losses in childhood, in particular, are considered as an important risk factors in adult

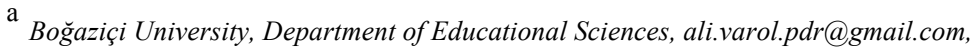
ORCID: 0000-0001-8633-9686

b Corresponding author: Boğaziçi University, Department of Educational Sciences, deniz.kaymak@boun.edu.tr,ORCID:0000-0002-6048-0814

c Boğaziçi University, Department of Educational Sciences, sibelakmehmet@boun.edu.tr, ORCID: 0000-0003-1793-067X

d St. Cloud State University, Department of SpecialEducation, mamarkell@stcloudstate.edu, ORCID: 0000-0002-9964-0168 
psychopathology (Kendler et al., 1992). Abrams (2013) described parental loss as "something that stays with you and shapes you for the rest of your life; it becomes a condition of your existence, like having blue eyes or black hair" (p. 17). In every case, grief counselors witness that loss of a loved one is not an experience to get over or to move on, but an experience to keep living by.

Understanding the impact of early parental loss on young adults is the main interest of this study. Various loss-related terms that include bereavement, grief and mourning have been used in the related literature. Below includes a brief review of these loss-related terms and the other terms that are believed to relate to loss.

Bereavement refers to a situation of having lost someone important through death. It can also be described as the psychological reactions of those who survive a significant loss (Stroebe et al., 2008). People who lose their parents, siblings, partners, friends or close relatives might experience intense distress and emotional disturbance (Bowlby, 1998). In terms of the depth of pain involved, probably next to a parent's loss of a child, comes a child's loss of a parent. The impact is so immeasurable that life can no longer be the same for the bereaved. Bereavement is a highly disruptive experience and is usually followed by a painful but time-limited period of acute grief (Shear \& Shair, 2005).

Grief is a primarily emotional response to loss, particularly to the loss of someone with whom the individual has an emotional connection. It is both a common humane reaction and a complex syndrome. Grief is like an illness with various negative physical (physiological-somatic) and psychological (social-behavioral, cognitive) manifestations. On the other hand, grief can also bring strength (Parkes \& Pigerson, 2013); as broken bones get stronger after a healing period, people people may become more mature after experiencing grief. Every individual experiences grief in a unique way (Rosenblatt \& Wallace, 2013). Some may have intense feelings of anger or loneliness; others may feel abandoned for a period of time or manifest delayed responses. Responses to parental death and the length of the grieving process are unique to each individual (Ellis \& Granger, 2002).

Mourning is a public display of grief. It is a psycho-biological reaction that occurs when beloved ones die (Lewis, 1979). Mourning is not a feeling to overcome, but a process to be adapted and reshaped. It is a natural and universal reaction, an adaptation to a new situation and a maturation process created in the inner world of a bereaved individual (Çevik, 2000). Beliefs and rituals shape the mourning traditions of cultures (Rubin \& Yasien-Esmael, 2004). Every culture has different social expressions of mourning. There is no right or wrong way of mourning; every individual experiences it in a unique way (Kıvılcım \& Doğan, 2014).

True appreciation of the impact of a loss on an individual requires that we have some understanding of the meaning of attachment (Worden, 2018). John Bowlby's Attachment Theory is a multidisciplinary theory that was formed by the interactions of different disciplines including psychoanalysis, etiology, socio-biology, psychobiology and modern theories of cognitive development (Popper \& Amit, 2009). Attachment is a universal phenomenon. It is a framework that conceptualizes the human tendency to create strong affectional bonds with others and a tendency to develop strong emotional reactions as well as different forms of protests when those bonds are threatened or broken. Erdman and Caffery (2013) indicated that the psychological aim of physical 
closeness for the attached person is the security in the presence of an attachment figure and the physiological aim of the system is survival. The emotional bond between the infant and the primary caregiver allows the baby to feel safe. That bond develops from birth through the first year of life (Wallach \& Caulfield, 1998). Infants show signs of attachment within the first 9 months of life, such as crying to show their emotional distress or clinging to maintain closeness to the primary caregiver. Bowlby (1972) asserted that infants feel that they are important and that they deserve to be loved and approved as a result of the relationship that they have established with the primary caregiver. This secure base forms the basis for the individual to develop positive internal working models for oneself and others.

In 1961, Mary Ainsworth and her colleagues designed a procedure called Strange Situations to assess the individual differences in attachment behavior of babies aged 12-18 months (Ainsworth \& Bell, 1970). It is carried out in a small room with a chair for the mother and toys for the baby on the floor. The experiment starts by taking the mother and the baby into the experiment room. The mother sits on the chair and frees the baby for him or her to explore and interact with the toys on the floor. After a while, the mother leaves the room for time periods of three minutes. In one of these separation cases, which is repeated twice, a research assistant stays with the baby. In the second case, the baby stays in the room alone. Babies' behaviors in these different situations are recorded (Ainsworth et al., 1978). On the basis of the results, attachment could be assessed as either secure or insecure. Ainsworth (1979) first described three principal patterns of attachment: anxious avoidant, secure, and anxious resistant. Anxious avoidant infants were described as being willing to explore independently but actively avoiding their caregiver upon reunion after a period of separation. They respond less positively to being held, but more negatively to being put down. Secure infants actively seek contact or interaction with the caregiver upon reunion after a period of separation. They exhibit a minimum level of resistant and avoidant behavior, and although they become somewhat upset when their caregiver leaves, they become calm upon the caregiver's return (Ainsworth, 1978). Anxious resistant infants experience difficulty separating from the caregiver in order to explore and find it difficult to settle down upon reunion after a period of separation. They concurrently seek contact with their caregivers as well as resist them.

Several years later, Brazelton and Yogman (1986) proposed another attachment pattern called disorganized/disoriented. It was observed that infants who were exposed to physical or emotional abuse by their primary caregiver tended to experience a dilemma. Their survival instincts tell them to flee to safety but the safety lies in the very person who scares the child. These infants exhibit conflicting reunion, demonstrated by confusion or apprehension, when the attachment figure returns.

Infant attachment patterns were adopted by Bartholomew and Horowitz (1991) into adulthood using a broader group of attachment figures who may include friends, romantic relationships, and family members. To describe adult attachment patterns, they used four adult categories: secure, dismissing, preoccupied and fearful. Bartholomew and Shaver (1998) defined those patterns in terms of two dimensions: positivity of a person's model of self and positivity of a person's model of others (Figure 1). The positivity of the self model shows the degree to which a person has internalized a sense of his or her self-worth. The negativity of the self model is associated with the degree of 
anxiety and dependency on the other's approval in close relationships. The positivity of the other model indicates the degree to which others are generally expected to be available and supportive. The other model is therefore associated with the tendency to seek out or avoid closeness in relationships. Thus, adults with secure attachment patterns perceive themselves as valuable and lovable, and others as accessible and responsive to them. Secure individuals have high self-esteem and autonomy; they feel comfortable about establishing closeness. It was suggested that having a secure attachment pattern affects individuals' self-perception positively (Kaya \& Öz, 2020), contributes to autonomy and self-efficacy ( $\mathrm{Li}$ et al., 2015), and is associated with fewer physiological and behavioral problems (Lim \& Lee, 2017). In the remaining three modes of (insecure) attachment, however, there is a negative internal working model of the self and / or others. The current research utilized this two-dimensional four-category model of adult attachment.

\section{Figure 1.}

Two-dimensional Four-category Model of Adult Attachment (Bartholomew and Shaver, 1998)

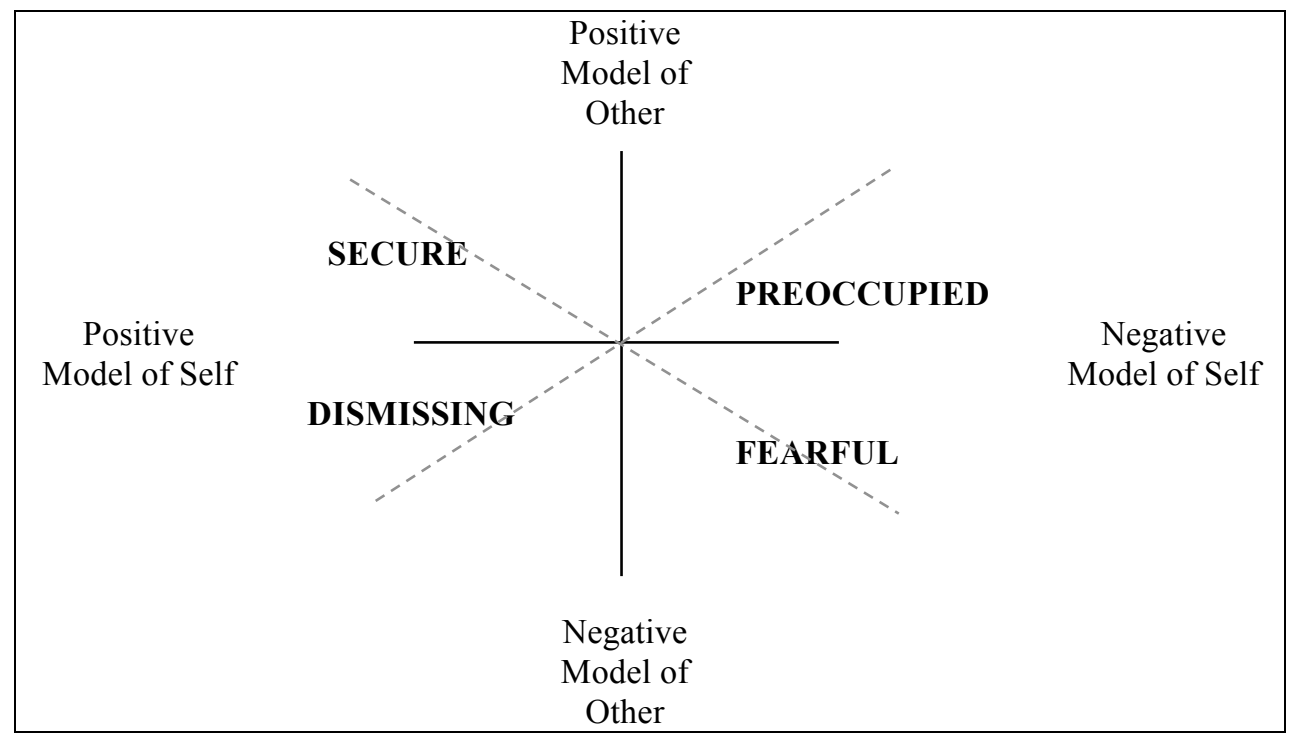

Individuals establish a preoccupied attachment pattern when they are exposed to inconsistently responsive early care-giving and therefore, they are characterized by low levels of self-esteem i.e., negative model of self (Wearden et al., 2005). They are also likely to have an idealized model of others, so they try to gain the approval and acceptance of others and become overly engaged with their relationships (Levy et al., 2011).

Due to rejection and harsh care-giving, some children develop a fear of intimacy fuelled by fear of rejection. These fearfully attached individuals share the negative view of self and they tend to have beliefs that they are not worthy of being 
loved and that others are refusing them. Hence, they avoid close relationships or have problems in their relationship. They have an unreturned desire to be accepted by others and a disposition to depression. This is largely because of their non gratifying relationships with others and strong fear of rejection (Yárnoz-Yaben, 2010). Both preoccupied and fearful attachment patterns (sharing the negative model of self) are found to be related to alexithymia (Wearden et al., 2005). Alexithymia is commonly considered to be an emotional blindness and is described as "a deficit in the ability to identify and describe emotions, but not to experience them, coupled with a tendency to externally oriented and concrete thinking" (Taylor et al., 1999, p. 30). People with this characteristic are likely to have difficulty in establishing emotional bonds.

Finally, individuals with dismissing attachment have a positive view of self and negative view of others (Bartholomew \& Shaver, 1998). They view themselves as valuable and lovable but have negative views about others. They avoid establishing close relationships so that they would not be disappointed or refused by others. They want to maintain their positive self-perceptions by trying to be independent and strong. This attachment pattern is believed to be related to consistently unresponsive early caregiving.

The pattern of parental attachment in infancy was shown to be the same as adulthood attachment in $72 \%$ of individuals 20 years after infancy. As predicted by the attachment theory, negative life events (including parental loss during childhood) were important factors in changing the attachment pattern for the remaining $28 \%$ of the participants (Waters et al., 2000).

People with different attachment patterns can exhibit different grief reactions (Field, 2006). Insecurely attached individuals have different physical, emotional, cognitive and behavioral grief reactions than securely attached individuals do (Stroebe et al., 2005; Wayment \& Vierthaler, 2002). Wayment and Vierthaler (2002) found that individuals with anxious-ambivalent attachment patterns reported greater levels of grief and depression after the death of a significant person. Luecken (2000) reported that parental loss in childhood is associated with health-damaging psychosocial characteristics in adulthood of individuals with insecure attachment patterns.

Beck (1979) stated that events that leave a trace on one's life such as parental loss may lead to the development of some basic dysfunctional beliefs or schemas about one's self and others. Schemas are core beliefs that maintain long-term psychological problems. On the basis of schemas, individuals are able to categorize and interpret their experiences in meaningful ways (Harvey et al., 1961). A person may develop negative schemas like 'I am no good' or 'others cannot be trusted' due to a variety of factors including serious life stresses and strains such as childhood abuse and parental death (Padesky, 1994). These schemes are automatic as they come to mind without one's control and lead to dysfunctional thoughts and beliefs about relationships, including romantic relationships that often start in early adolescence. Romantic relationships are defined as "relationship types involving intense attractions such as idealization of the other within an erotic context and expectation of enduring some time into the future" (Jankowiak \& Fischer, 1992, p. 150). Kernberg (1998) emphasized that people establish romantic relationships based on their desire to be loved by others and as driven by their sexual instincts. Ainsworth (1978) stated that individuals seek secure and supportive 
environments in their family starting from infancy and continue looking for that secure environment in their romantic relationships during adulthood.

As this study targets an understanding of the impact of early parental loss experiences on young adults, dwelling on romantic relationships is important (Widick et al., 1978) as well as functional. Inclusion of romantic relationships seemed necessary since it is a developmental task for this age group. In Erikson's (1994) theory of lifespan psychosocial development, personality evolves in a pre-established order through the eight stages in each of which individuals experience particular psychosocial crises. Each of these crises reflects a developmental task unique to that stage and the successful solution results in positive outcomes for personality development as well as acquisition of basic virtues like hope, will, purpose, and fidelity (Erikson, 1982). And on the contrary, failure to master these tasks timely does not only result in a stagnation of development, but also to shame, guilt, inferiority, and an identity crisis. Our participants are young adults whose ages range between 19-29, and therefore, they are at the sixth Eriksonian developmental stage with a potential conflict between intimacy and isolation. Ideally, they are to establish mutually satisfying intimate and romantic relationships. This study included romantic relationship beliefs instead of actual relationship satisfaction, because not everyone is in a romantic relationship but each individual inevitably carries beliefs regarding relationships. Lastly, inclusion of romantic relationships seemed functional because change in irrational beliefs can be a counseling goal and that change eventually leads to improvement and satisfaction in actual relationships.

The terms explained above are interrelated in multiple ways. For example, Hazan and Shaver (1987) conceptualized romantic relationships as part of the adult attachment process. Adult attachment has been found to be associated to relationship beliefs and romantic relationship experiences (Beştav, 2007; Brennan \& Shaver, 1998; DiGuiseppe \& Zee, 1986; Ellis, 2003; Hamamc1, 2007; Hammond \& Fletcher, 1991; Pascuzzo et al. 2013; Senchak \& Leonarkd, 1992; Stackert \& Bursik, 2003; Sullivan \& Scwebel, 1995). While there is an abundance of foreign literature linking attachment patterns and dysfunctional beliefs about romantic relationships, we failed to find related studies in Türkiye. The present study targets this issue to fill the gap by focusing on young adults with early parental loss as compared to young adults with no such loss. We included unalterable variables like loss status and attachment patterns as well as alterable variables like mourning reactions and romantic relationship beliefs to achieve both a theoretical understanding and potential practical implications for mental health professionals.

\section{Literature Review}

\section{Parental Loss in Young Adults}

Loss of a parent is a serious challenge to the maintenance of supportive and positive family environments. There are inevitable direct and indirect consequences of a parent's loss. It is not just that the child loses a parent, but also the remaining primary caregiver who survived through partner loss might be unable to show consistent, predictable and reliable care for the child. Inconsistent and unreliable parental care in 
early development of parentally bereaved children may lead to difficulties in establishing secure attachment bonds in later relations (Bowlby, 1980). Taking premature responsibility at an early age due to parental loss might cause fragility in the bereaved child's future life and marital relations (Şentürk, 2006). Fulton and Markusen (1971) also claimed that individuals who experience parental loss during childhood might suffer long-term vulnerabilities in medical, psychological and behavioral areas during adulthood. Birtchnell (1972) found that experiencing maternal loss before age 10 was an etiologic factor in the development of mental illness, such as depression. Earlier, Birtchnell (1970) reported that twice as many depressed suicide attempters were parentally bereaved compared to non-suicidal depressives. In a study with 118 adolescents who lost a loved one in the last five years, it is reported that proximal loss predicted depression (Reid \& Dixon, 2000). In addition, a recent causal comparative study with 256 young adults indicated that parental loss in adolescence was associated with a weakened psychosocial development and the impact did not change depending on participant demographic characteristics and loss related variables (Tuazon \& Gressard, 2021).

Young adults often worry about death. They also start to perceive their own death as a distinct possibility (Corr \& Corr, 2013). In this respect, one of the consequences of death of a parent for the bereaved is re-evaluation of the self and relations with others. Nickerson et al. (as cited in Corr \& Corr, 2013, p. 4-5) argued that young adults start to question their past life, previous experiences and future goals. Quality of child-parent relationships, therefore, may define later psychological and interpersonal functioning of individuals with parental loss. Parental loss during young adulthood may also affect the establishment of future attachments. Bereaved young adults might have difficulty in achieving intimacy in future relations as they fear losing another loved one (Walter \& McCoyd, 2015).

Despite the evidence for the presence of potential risk factors, many children with early parental loss do not experience major psychological, behavioral or medical problems. This may be due to the presence of protective factors like an ongoing secure relationship with a surviving parent or a family member, school-based interventions and professional help (Akerman \& Statham, 2014).

\section{Parental Loss and Mourning}

Individuals who experience loss of loved ones might experience mourning in different ways. They may experience psychological injuries after loss, thus they may need professional assistance (Bonanno \& Kaltman, 2001). During the mourning response period, emotional, social, cognitive, physical and behavioral responses might be seen such as unbelief, dullness, guilt, loneliness, blaming oneself for not preventing loss, blaming others (Willis, 2002), loss of appetite, withdrawal in social and physical activities (Dyregrov, 2006), decreases in academic performance and loss of effectiveness in professional life, experiences of psychosomatic pain and illness, lack of energy and sleeping disturbances (Çevik, 2000).

One of the reactions of young adults to parental death is to avoid interacting with their peers and family members. Bereaved young adults tend to lose their interest in interpersonal activities. They might feel abandoned and have excessive levels of 
anger along with deterioration in sleep patterns. They tend not to be able to participate in normal or work-related activities with joy (Scharlach, 1991).

Parental loss mourning processes during young adulthood are influenced by many factors, including age, gender, biological sex, and relationship quality. Carver et al. (2014) found that gender of the individual who experienced parental loss was significantly important in predicting some aspects of grief. It has been reported that women are more influenced than men by parental loss; irrespective of the deceased parent's gender. Interaction between genders of parent and child was also significant; women reported that maternal loss may be particularly more difficult for them than men, suggesting that women might have stronger emotional experience of grief. Another research (Hayslip et al., 2015) found that women have more difficulties in adjusting to parental loss than men do. These findings, of course, could also be due to the self-report nature of the data, as women tend to be less defensive in accepting psychological concerns than men.

Another factor influencing parental loss seems to be the time. In fact, recent research also shows that as more time passes after the loss, the emerging adults better adapt to the situation thus, a decrease in the intensity of their mourning reactions is expected (Jones \& Martini, 2021).

\section{Parental Loss and Romantic Relationships}

Parkes and Weiss (1983) asserted that people who lose the person on whom they most depend as a secure base and safe haven are the most vulnerable ones to despair. People who lost a member of their immediate family may experience psychological problems and this situation influences their future relationships (Barner \& Rosenblatt, 2008). Young adults with parental loss tend to exhibit avoidance of intimacy towards their partners (Hepworth et al., 1984).

Ellis (1986) claims that parental loss might have effects on individuals' beliefs about their romantic relationships as well. Generalizing loss and not being able to handle that experience can lead individuals to develop dysfunctional beliefs about relationships with the fear of abandonment and rejection (Carter \& Sokol, 1988), and losing control over relationships (Hatfield \& Rapson, 1993) after the irrecoverable and uncontrollable loss of a loved one. Epstein and Eidelson (1981) reported that individuals with dysfunctional relationship beliefs might have difficulty ending their romantic relationships whether their relationship satisfaction is high or not. High levels of dysfunctional beliefs were also found to relate to unhappiness and low levels of satisfaction in relationships (Fincham \& Bradbury, 1987).

\section{Attachment and Mourning}

According to the attachment theory, one's attachment pattern plays an important role in determining the individual differences in responses exhibited following the loss of a close one (Bowlby, 1998). Neimeyer et al. (2011) indicated that attachment pattern predicts ways of dealing with emotions and handling stressful situations in particular ways of coping with bereavement; and, as a consequence, it also predicts psychopathology and grief reactions (Stroebe \& Shut, 2005). 
Securely attached individuals are expected to recall their memories about the deceased and share these memories with others as this is considered to be a normal mourning reaction. They have fewer depression symptoms than other attachment groups after loss (Wayment \& Vierthaler, 2002). Dismissing individuals, on the other hand, suppress their feelings about the loss and therefore they tend to have absent or inhibited grief reactions. Also, individuals with preoccupied attachment have high levels of emotional reactions toward loss. Their bond to the deceased would be too strong and they would be too dependent on and cling too much to the tie to be able to reconcile the grief, thus, experiencing chronic grief. Finally, people with disorganized attachment patterns might not be able to coherently think about the attachment-related memories and have traumatic grief reactions (Stroebe et al., 2005).

\section{Attachment and Romantic Relationships}

The quality of a person's relationship with other adults is determined by the attachment relationship that the individual has with his/her primary caregiver who is most likely to be the mother (Bowlby, 1980). Hazan and Shaver (1987) conceptualized adult romantic relationships as parallel to an individual's very first relationship: infant to mother. Childhood attachment quality has an impact on the quality of adult relationships in the following years (Banse, 2004). Studies found a significant relationship between individuals' attachment patterns and their romantic relationship satisfaction (Hammond \& Fletcher, 1991; Lussier et al., 1997; Senchak \& Leonard, 1992). Whisman and Allan (1996) claimed that there is a modest convergence between romantic relationship beliefs and adult attachment patterns of individuals.

Individuals who established positive attachment relations with their primary caregivers during the infancy period establish positive close relationships with others in adulthood. Likewise, individuals who have negative attachment relations with their primary caregivers in early years of life establish insecure attachment during adulthood (Waters et al., 2000). The secure attachment pattern was related to greater relationship satisfaction, trust, interdependence, and commitment than the other insecure attachment patterns (Simpson, 1990). Feeney and Noller (1990) reported that the attachment pattern of individuals is related to attachment history and to beliefs about relationships. Stackert and Bursik (2003) found that both relationship specific dysfunctional beliefs and insecure adult attachment patterns (preoccupied, dismissing, and fearful) were related to diminished relationship satisfaction.

The three attachment patterns of Ainsworth exist in adulthood and form the romantic relationship experiences (Brennan \& Shaver, 1998). Insecurely attached individuals tend to lack physical comfort and nurturance in their romantic relationships (Feeney \& Collins, 2004). Secure individuals tend to provide care for their partners for more altruistic reasons (Collins et al., 2006), whereas people with avoidant attachment offer care for egoistic reasons (Mikulincer et al., 2005). Avoidant individuals tend to maintain greater emotional distance and avoid physical and emotional situations that may create intimacy. They also engage in sexual activities less often (Brassard et al., 2007; Tracy et al., 2003).

Hazan and Shaver (1987) claimed that people with different attachment patterns have different beliefs about romantic relationships. Beştav (2007) asserted that 
attachment patterns of a sample of university students in Türkiye were found to be related to their dysfunctional relationship beliefs and associative attitudes. Securely attached and fearfully attached students tended to have the dysfunctional belief that 'disagreement is disruptive.' In addition, the preoccupied group were prone to have the dysfunctional belief that 'relationship needs are different' and finally, the dismissing group tended to have the dysfunctional belief that 'women and men cannot understand each other.'

In the light of the literature reviewed above, this study aimed to investigate whether attachment patterns of young adults differ depending on the presence or absence of early parent loss; whether the relationship between attachment patterns and dysfunctional romantic relationship beliefs differ depending on the presence or absence of early parent loss; whether the mourning level influences the relationship between attachment pattern and romantic relationship beliefs; and finally, the most common styles of mourning among the bereaved young adults. The first two questions compared the two groups utilizing the entire sample, while the last two questions utilized only the loss group subsample.

\section{Method}

\section{Participants}

Cooperation was established with the student counseling center of a public university in İstanbul. Through two e-mail invitations, separated by a week, students were asked to join the study. A total of 416 students (response rate: $2,58 \%$ ) volunteered to participate. An attempt was made to increase the sample size by social media postings at the university and 149 students responded to the call. Thus the sample size increased to 565 students. Potential risk of reanswering the survey was prevented by filtering computer identity numbers of all respondents.

The following exclusion criteria were used: Participants whose age was older than 29; parental loss occurred after the age of 18; parental separation or divorce; and loss of both parents. After the data of these participants $(f=142,25 \%)$ were eliminated, $423(75 \%)$ students from the original sample remained.

Of the total 423 participants, 64 (15\%) of them constituted the loss group, and $359(85 \%)$ of them constituted the no loss group. Demographic characteristics of both groups were comparable, except that the loss group reported a slightly higher socioeconomic status (SES) than the no loss group: $41(9.7 \% ; 17.2 \%$ vs. $8.4 \%)$ as high, $337(79.7 \%$; $70.3 \%$ vs. $81.3 \%)$ as middle, and $45(10.6 \% ; 12.5 \%$ vs. $10.3 \%)$ as low. Of all participants $295(70 \%)$ defined themselves as women, $110(26 \%)$ as men, $14(3 \%)$ as LGBTI+, and four (1\%) of them provided no definition of gender. The mean age of participants was $22.62(S D=2.83)$. In terms of educational level, $85(20.1 \%)$ were senior, 75, (17.7\%) were English Preparatory School, 74 (17.5\%) were Master's, 69 $(16.3 \%)$ were freshman, $56(13.2 \%)$ were sophomore, $53(12.5 \%)$ were junior and 11 $(2.6 \%)$ were PhD students, respectively. And finally, 207 (48.9\%) had one sibling, 99 $(23.4 \%)$ had two siblings, 49 (11.6\%) were a single child, $41(9.7 \%)$ had three siblings, $18(4.3 \%)$ had four siblings, and nine $(2.1 \%)$ had five or more siblings. Nearly half of the students $(205,48.5 \%)$ reported that they were currently in romantic relationships, 
about one third of them $(131,31 \%)$ stated that they were not currently in a relationship, and about one fifth of them $(87,20.6 \%)$ reported that they were never in a romantic relationship.

In the loss group, $51(80 \%)$ of the participants experienced father loss, and 13 $(20 \%)$ of participants experienced mother loss. The average age of loss experienced is $11(S D=5.58)$ with a range of zero (from birth) and 18. Age of parents at the time of death ranged between 27 and 84 ( $\mathrm{SD}=11.12$ ) with an average of 49 . Reasons of parental death were as in the following: 34 (53.1\%) were from a sudden disease (heart attack, rapidly spreading cancer, etc), 16 (\%25) died of chronic disease (diabetes, slowly progressing cancer, etc.), eight (12.5\%) had a fatal traffic accident, three $(4.7 \%)$ had fatal home accidents and two $(3.1 \%)$ committed suicide and one $(1.6 \%)$ had undefined reasons. Forty-three $(67.2 \%)$ of the bereaved participants reported that they were in good relations with their deceased parent, $11(17.2 \%)$ as they were too young to establish any kind of relationship, seven (10.9\%) defined their relationship quality as complicated, and three $(4.7 \%)$ as their relations were bad. Eighteen $(28.1 \%)$ of the participants received psychological/psychiatric support after loss, whereas $46(71.9 \%)$ of them never asked for professional help. Eleven (61\%) of the participants who reported to have received help reported that the help is still ongoing.

\section{Instruments}

All the data collection tools were administered through an online platform named Survey Monkey. At its beginning, there was an explanation about the research and an informed consent form which proceeded with a link to the instruments that included the Demographic Information Form, the Mourning Scale, the Relationship Scales Questionnaire, and the Relationship Belief Inventory, in that order. For participants who marked no experience of parental loss, the Mourning Scale was automatically skipped. It took about 10 minutes to complete the survey.

Demographic Information Form. A demographic information form was developed to describe the sample characteristics. The form consisted of questions about participants' relationship status and loss experiences as well as a number of descriptive characteristics including age, education level, gender (asked in an open-ended form "How do you define your sexual identity i.e., man, woman, trans, intersex, etc."), SES, number of siblings, and parental status. Some questions were meant only for the participants in the loss group.

Mourning Scale. The Mourning Scale (MS) was developed by Balcı-Çelik (2006) as based on Beck (1979) and Bowlby's (1998) theoretical formulations about loss. It was designed to assess physical, emotional, cognitive and behavioral changes in bereaved individuals after loss experiences. It consists of 35 Likert-type items to be scaled on 5 points (1-5). Scores range between 35 and 175, higher end indicating the strength of cumulative mourning signs. The structural compositions have four factors; physical ( 5 items related to changes that occur in the body of the individual in the state of mourning), emotional (10 items related to various emotional symptoms), cognitive (10 items related to mental states in mourning), and behavioral (10 items on observable 
manifestations of mourning). The Beck Hopelessness Scale was used to obtain concurrent validity and yielded supportive results $(r=.80)$ (Balc1-Çelik, 2006). Data obtained from young adults aged between 18-24, in the years 2000-2003, supported the internal consistency of the measure with a Cronbach's alpha of .96 and the stability coefficient of .84 (Balc1-Çelik, 2006). Cronbach's alpha values were sufficiently high both in the original study $(.65, .90, .81$ and .62 for physical, emotional, cognitive and behavioral scales, respectively) and in our own analyses $(.77, .73 ., .81$ and .82 for the scales in the same order and .93 for the entire measure).

Relationship Scales Questionnaire. The Relationships Scales Questionnaire (RSQ) was developed by Griffin and Bartholomew (1994). It consists of 18 statements which yield four prototypes of attachment patterns, namely, secure, fearful, preoccupied and dismissing. Scores for each attachment pattern are derived by four or five items representing each attachment type. Items are responded to on a 7-point Likert type scale. Higher scores point to insecure attachment.

Griffin and Bartholomew (1994) found that the alpha values of the scale varied between .41 and .71 and the test-retest reliabilities were .53 for women and .49 for men (as cited in Sümer \& Güngör, 1999, p. 82). Sümer and Güngör (1999) conducted the reliability and validity studies of the RSQ by Turkish samples and found that the testretest correlation coefficients with an interval of four weeks ranged between .54 and .78 . In a cross-cultural comparison with the United States sample, the Turkish RSQ showed satisfactory levels of internal consistency, stability and convergent validity (Sümer \& Güngör, 1999). Reliability statistics for the RSQ as calculated by Cronbach's alpha values for the original scale (total: $.82 ; .59, .33, .30$ and .80 for the secure, fearful, preoccupied and dismissing patterns, respectively) and in the current study (total: .84; $.52, .75, .46$ and .75 in the same order) were satisfactory.

The Relationship Belief Inventory. The Relationship Belief Inventory (RBI) was developed by Romans and DeBord (1995) to measure dysfunctional beliefs about relations. The original form of the scale consists of 142 items in Likert-type scale format. Its adapted Turkish version consists of 37 items and six factors that indicate a different dysfunctional belief about romantic relationships: "We should be completely open and honest with each other," "We should be able to read each other's minds," "We should do everything together," "We should be able to meet all of each other's needs," "We should be willing and able to change for each other," and "Romantic idealism" (Gizir, 2012). These factors together form a one-dimensional structure. The total score ranges from 37 to 185, high scores indicating dysfunctionality. The Cronbach's alpha values of each factor range between .78 and .89 . The Cronbach's alpha value of the entire scale was found to be .95 in the adaptation study and it was .93 in the current study.

\section{Data Analysis}

Statistical Package for the Social Sciences (SPSS) version 21.0 was used for statistical analyses. Descriptive statistics (frequencies, means, standard deviations, maximum and minimum scores, and percentages), repeated measures of multivariate analysis of 
variances (MANOVA), Pearson Product Moment correlation coefficients, chi-square test for goodness of fit were the analyses used to answer the research questions. Before running the analyses, assumptions for normality, homogeneity, linearity, and equality of covariance matrices were checked. All scores on the variables were normally distributed and no univariate or multivariate outliers were detected.

\section{Results}

Results are organized in the same order of the research questions.

\section{Attachment Pattern Differences between the Early Parental Loss and No Parental Loss Groups}

Through repeated measures of multivariate analysis of variance (MANOVA), differences between the loss and no loss groups were analyzed for four dependent variables as obtained from the four factorial scores of the RSQ that measured attachment patterns of secure, preoccupied, dismissing, and fearful types. As seen in Table 1, the means of the four attachment pattern scores were very similar for the early parental loss and the no loss groups. MANOVA results suggested that the loss status group differences in four attachment pattern scores were not statistically different $(F$ $(4,418)=1,482, p>.05)$. Therefore, there was no foundation to argue that attachment patterns differed depending on parental loss status.

\section{Table 1}

Means and Standard Deviations of the Four Attachment Patterns among Young Adults with and without Parental Loss

\begin{tabular}{llll}
\hline & Loss Status & $M$ & $S D$ \\
\hline Secure & Early Parental Loss & 3.85 & .93 \\
& No Parental Loss & 3.96 & .92 \\
\hline Preoccupied & Early Parental Loss & 4.38 & 1.03 \\
& No Parental Loss & 4.30 & 1.10 \\
\hline Dismissing & Early Parental Loss & 4.39 & 1.07 \\
& No Parental Loss & 4.50 & 1.15 \\
\hline Fearful & Early Parental Loss & 3.75 & 1.32 \\
& No Parental Loss & 3.82 & 1.15 \\
\hline
\end{tabular}

Relations between the Dysfunctional Romantic Relationship Beliefs and Attachment Patterns for the Early Parental Loss and No Parental Loss Groups

Pearson Product Moment correlation coefficients between the continuous scores of the two measures, attachment patterns and dysfunctional romantic relationship beliefs were separately calculated for the loss group and the no loss group. As shown in Table 2, for 
the loss group there was a low but positive correlation between the dismissing attachment patterns and the dysfunctional romantic relation beliefs $(r=.253, n=64, p<$ $.05)$ with high levels of dismissing attachment patterns associated with high levels of dysfunctional beliefs and vice versa. In the no loss group, there was a positive association between preoccupied attachment patterns and dysfunctional romantic relationship beliefs $(r=.233, n=359, p<.001)$ suggesting that high levels of preoccupied attachment scores were associated with high levels of dysfunctional romantic relationship beliefs and vice versa.

\section{Table 2}

Pearson Product Moment Correlation Coefficients between the Total Dysfunctional Romantic Relationship Beliefs and the Four Attachment Patterns among Young Adults with and without Parental Loss

\begin{tabular}{lcc}
\hline & $\begin{array}{c}\text { Dysfunctional Romantic } \\
\text { Relationship Beliefs of } \\
\text { Early Parental Loss Group } \\
(n=64)\end{array}$ & $\begin{array}{c}\text { Dysfunctional Romantic } \\
\text { Relationship Beliefs of } \\
\text { No Parental Loss Group } \\
(n=359)\end{array}$ \\
\hline Secure & $r$ & $r$ \\
Preoccupied & -.080 & .032 \\
Dismissing & .166 & $.233^{* *}$ \\
Fearful & $.253^{*}$ & -.094 \\
\hline Significance testing & .064 & .031
\end{tabular}

Significance testing was 2-tailed. $* p<.05, * * p<.0001$

\section{The Role of Mourning Level in the Attachment Patterns and Dysfunctional Romantic Relationship Beliefs}

Cumulative percentages of the MS scores were used to make up three groups depending on mourning level; the top one third percentile of the participants were considered as the high $(M=115.5,34.4 \%)$, the middle third percentile were considered as the moderate $(M=90.2,31.2 \%)$, and the bottom third percentile constituted the low $(M=73,34.4 \%)$ levels of mourning groups. Then Pearson Product Moment correlation coefficients between the attachment patterns and the dysfunctional romantic relationship beliefs were calculated separately for the three mourning levels. As shown in Table 3, for the high mourning group, a moderately positive significant correlation was found between the dismissing attachment patterns and the dysfunctional romantic relationship beliefs $(r$ $=.567, n=22, p<.01)$. There were no significant relations between the attachment patterns and dysfunctional romantic relationship beliefs at low and moderate levels of mourning and there was no significant relation at other attachment patterns. It is suggested that the level of mourning reactions influenced the association between the dismissing attachment patterns of individuals and their dysfunctional beliefs about romantic relationships. Highly mourning individuals with a dismissing attachment pattern appeared to hold more dysfunctional romantic relationship beliefs than the other groups. 
Table 3

Pearson Product Moment Correlation Coefficients between the Total Dysfunctional Romantic Relationship Beliefs and the Four Attachment Patterns by Three Levels of Mourning among Young Adults

\begin{tabular}{lccc}
\hline & $\begin{array}{c}\text { High Level of } \\
\text { Mourning } \\
(n=22)\end{array}$ & $\begin{array}{c}\text { Moderate Level of } \\
\text { Mourning } \\
(n=20)\end{array}$ & $\begin{array}{c}\text { Low Level of } \\
\text { Mourning } \\
(n=22)\end{array}$ \\
\hline Secure & $r$ & $r$ & $r$ \\
Preoccupied & -.093 & .050 & .027 \\
Dismissing & .270 & .016 & .197 \\
Fearful & $.567^{*}$ & -.124 & .034 \\
\hline
\end{tabular}

Significance testing was 2-tailed. $* p<.01$

\section{Types of Mourning Reactions among the Loss Group}

To identify which of the four mourning reactions (behavioral, physical, emotional and cognitive) is more common among the parentally bereaved participants, one sample chisquare test was used. Table 4 shows the descriptive statistics for the four subscales. According to the most intense mourning reactions that they reported, participants were categorized into four mourning reactions. Nine participants could not be classified in any single predominant mourning reactions, and therefore had to be excluded from the analysis. Chi-square test for goodness of fit test conducted with 55 as the remaining sample size indicated that mourning reactions were statistically different $\left(\mathrm{c}^{2}(3, n=55)\right.$ $=25.6, p<.001)$. Behavioral mourning reactions were the most commonly observed or dominant mourning reaction $(f=34)$. Physical mourning reactions were the second common $(f=11)$ and emotional mourning reactions were the third common $(f=8)$ type. The least common type was cognitive mourning reactions $(f=2)$.

\section{Table 4}

Means * and Standard Deviations of the Four Mourning Reactions for the Lost Group $(n=64)$

\begin{tabular}{lcc}
\hline Subscales & $M$ & $S D$ \\
\hline Behavioral & 3.82 & .848 \\
Physical & 3.55 & .799 \\
Emotional & 3.36 & .645 \\
Cognitive & 2.89 & .639 \\
\hline
\end{tabular}

*Subscales had different number of items, therefore for comparative purposes, their averages were used. 


\section{Discussion}

Prior research suggested that negative life events, like early parental loss, may change individuals' attachment patterns (Waters et al., 2000). Therefore, one might have expected more insecure attachment patterns among the bereaved young adults. However, we found no attachment pattern difference between the early parental loss and no loss groups. We should point out, however, that the two groups were different only in absence and presence of parental loss and there were multiple other important losses in both groups. It happened that the no loss group had more grandparent (40\% vs 18\%), and other multiple important losses $(18 \%$ vs $0 \%)$ than the loss group had. On the other hand, the loss group had more close relative (42\% vs $12 \%)$ and family friend (28\% vs $6 \%$ ) losses. One potential explanation could be related to the traditional i.e., extended family structure in Türkiye (Canatan, 2009). Children are typically raised by their grandparents who might function as significant attachment figures. It is possible that prevalence of more grandparent and multiple other losses in the no loss group decreased potential differences between the two groups. Another explanation could be that secure attachment bonds were established with the surviving parents most of whom, in our sample, were mothers who tend to be the primary attachment figures. Further studies are needed to clarify the effects of strong bonds with grandparents and surviving parents on bereaved young adults.

In addition, for both groups, the most common attachment patterns were preoccupied $(f=129,30.5 \%)$ and dismissing $(f=119,28.1 \%)$, while secure $(f=86$, $20.3 \%)$ and fearful $(f=57,13.5 \%)$ patterns were much less observed $(f=32,7.6 \%$ could not be classified). This finding was surprising, because we expected to find mostly secure attachments at least for the no loss group. Indeed, in a meta-analysis of more than 200 adult attachment studies conducted with North American samples of 10,500 individuals (George et al., 1985), more than half of the participants had predominantly secure attachment patterns, while less than a quarter had dismissing and about one fifth had preoccupied attachment patterns (fearful pattern was not included). On the other hand, Van IJzendoorn and Bakermans-Kranenburg (2010) reported that young adults and student samples contained a higher proportion of dismissing attachment classifications than the normative groups. Similar inconsistent findings exist in the Turkish literature as well. A Turkish study with a sample from a private university found that the prevalence of attachment patterns was as in the following: secure $(45.6 \%)$, preoccupied (\%23), fearful $(17.27 \%)$, and dismissing $(14.13 \%)$ attachment patterns (Tokuş, 2014). Yet, in another study conducted at a public university with a student population comparable to our sample, showed that the preoccupied attachment pattern constituted a larger group $(f=104,33.3 \%)$ than those with secure $(f=88$, $28.2 \%)$ and dismissing $(f=75,24.03 \%)$ attachment patterns (Pancaroğlu, 2007). Again, like our findings, fearful attachment $(f=45,14.42 \%)$ was the least common pattern in that study (Pancaroğlu, 2007). These contradictory findings could be attributed to population characteristics i.e., studying at a public or private school as an indicator of SES. In fact, one might expect that hardships may directly or indirectly influence parental sensitivity and thus attachment. Supportive evidence exists for this expectation that through an examination of data from 54 countries; Schmitt et al. (2004) found that 
in resource limited countries insecure (both preoccupied and dismissing) attachment styles were more prevalent. We need future normative studies on attachment controlling for SES differences before reaching any conclusion.

Studies conducted in Türkiye and elsewhere showed significant relations between attachment patterns and dysfunctional romantic relationship beliefs (Beştav, 2007; Feeney \& Noller, 1990; Pascuzzo et al., 2013; Stackert \& Bursik, 2003; Whisman and Allan 1996) and we wanted to see what patterns of insecure attachment were more vulnerable and whether potential vulnerabilities change due to early parental loss status. Our findings indeed showed an interplay between attachment pattern and dysfunctional romantic relationship beliefs that changes depending on the loss status. Young adults with parental bereavement reported more dysfunctional romantic relationship beliefs if they had dismissing attachment pattern. Yet, young adults with intact families reported more dysfunctional romantic relationship beliefs if they had a preoccupied attachment pattern. No significant association was established for secure and fearful attachments for either groups.

Ellis (1957) indicated that dysfunctional beliefs occur when individuals have negative thoughts about the world due to irrational, unrealistic and negative perceptions about self or others and having insecure attachment patterns may negatively affect individuals' relationships (Feeney \& Noller, 1990; Stackert \& Bursik, 2003; Whisman \& Allan, 1996) through shaping their perceptions. In fact, negative self-image is found to exist in the preoccupied attachment patterns of the Bartholomew and Shaver (1998), and negative others-image exists in the dismissing attachment patterns. Therefore, people with both attachment patterns may be expected to have dysfunctional relationship beliefs. We found that these dysfunctional beliefs changed depending on both the attachment pattern and the early parental loss status. Dysfunctional relationship beliefs were found to relate to the parental loss group with dismissing attachment patterns, while those beliefs were found to relate to the no parental loss group with preoccupied attachment patterns. This was a unique and puzzling finding indicating an opposite direction (negatively valued self vs. other) as influenced by parental loss status. The dismissing attachment pattern was more dysfunctional in terms of romantic relationship beliefs for young adults who experienced early parental loss, while the preoccupied attachment pattern was more dysfunctional in the same regard for young adults who did not experience parental loss. Since there was no other literature to compare our findings, it was difficult to argue for moderation effect or to offer an informed explanation. We need to wait for future couple and family studies, especially those that investigate both partner satisfaction and dysfunctional relationship beliefs, to reach a better understanding.

No elevations in dysfunctional romantic relationship beliefs were observed among individuals with fearful attachment pattern regardless of their parental loss status. Fearfully attached individuals hold negative model of self and others. While they tend to worry about being rejected in their relationships with others (Bartholomew \& Horowitz, 1991; Williams et al., 2013), they may also internalize the idea that the death of a parent is also just another rejection that they experience in the family after being exposed to a distant and unsupportive parent in the past (Widom et al., 2018). Therefore, it was expected that parental loss may not change their relationship patterns and negative internal models about self and others. Evidence exists that individuals with 
fearful attachment patterns may not show stable, consistent mourning reactions after parental loss as they already had distant and inconsistent care of parenting when their parents were alive (Dean, 1988; Worden, 2018). Most students reported positive relations with their deceased parents, therefore these explanations are to remain only at a theoretical level, until controlled studies are conducted.

Individuals with secure attachment patterns have positive perceptions about themselves and others. They do not suppress their feelings about the loss and have fewer depression symptoms after a loss than do individuals with other attachment patterns (Lim \& Lee, 2017; Wayment and Vierthaler, 2002). Harmful effects of the parental loss experience may not be seen in securely attached individuals as much as in the insecurely attached ones (Illene, 2000). Therefore, it was expected to observe fewer changes in individuals with secure attachment patterns after parental loss experience about their perception and beliefs about others in their relationships. This may be the reason within the secure attachment pattern even for individuals with early parental loss experience there was no increase in dysfunctional romantic relationship beliefs as there was also none for the individuals with no parental loss.

We already established that the dismissing attachment pattern and dysfunctional relationship beliefs were positively associated among the bereaved young adults. As in grief therapies, understanding mourning reactions is a must in understanding an individual's loss experience. There was an indication that high levels of mourning reactions even after three years of loss are accepted as chronic mourning reactions (Stroebe et al., 2005). Therefore, we wanted to take a further step and see whether the existing association changed depending on the level of mourning. The analyses showed that it did. Among the three (high, moderate and low) mourning levels, only at high level, a significant positive relationship between the dismissing attachment pattern and dysfunctional beliefs was observed. If the mourning reactions were at moderate or low levels, the associations were similar for the loss and no loss participants. This was another unique contribution of this study. The observed influence of mourning reactions seems to support Hepworth et al.'s (1984) findings that the mourning process might directly or indirectly affect romantic relationship patterns. High levels of mourning reactions after parental loss are likely to lead to dysfunctional romantic relationship beliefs.

After examining the influence of mourning levels, this study also explored the predominant mourning reaction types among the bereaved young adults. Prior research suggested that behavioral mourning reactions, as indicated by disturbances in eating, avoiding social environments due to the feeling of insecurity and forcing oneself to do fun activities to suppress the effects of loss, were the most common mourning reactions (Waldinger et al., 2007). Our results confirmed that the majority (61\%) of the parentally bereaved individuals showed behavioral mourning reactions as their predominant mourning type.

The second most common mourning reactions $(20 \%)$ of our participants were the physical type. Physical mourning reactions include crying, disturbance in sleeping patterns, having nightmares, and being tired and weak. These reactions in nature are similar to behavioral reactions and these two had the highest intercorrelation $(r=.79)$. It was expected to find significant correlations among the mourning reaction types because they are all natural and universal reactions that each individual may experience 
after loss (Dyregrov, 2006; Willis, 2002). However, the weaker intercorrelations were between the physical and cognitive $(r=.48)$, behavioral and cognitive $(r=.50)$, and physical and emotional $(r=.54)$, while the others were relatively moderate; emotional and cognitive $(r=.66)$, and finally, behavioral and emotional $(r=.64)$ in our sample (all two tailed, $p<.001)$.

After the parental loss experience, individuals may experience serious conditions, such as post-traumatic stress disorder (PTSD, Şenkaya-Dildar, 2000). Recreation of the traumatic experience, the occurrence of the repeated behaviors, changes in the attitudes and manners, and chronic mourning reactions are the characteristic features of PTSD after the loss of a loved one. Knowing that the most common mourning reactions tend to be directly observable i.e., the individuals who may be in need of support are likely to provide identifiable signals, may ease the assessment process of the bereaved individuals.

The third in order of mourning reactions was the emotional type (14.5\%) for our participants. These emotional mourning reactions include feelings such as sadness, fatigue, and denial. Expression of the emotional mourning reactions has been emphasized as helpful in the healing process of individuals during the first few years of the loss experience (Pollock, 1961; Rogers, 2011), but it is also suggested that not all bereaved individuals need to show these reactions (Cordell \& Thomas, 1997). These reactions are much less explicit than the other three types.

The last type of mourning reaction in our sample was cognitive $(3.6 \%)$. These cognitive mourning reactions include distorted and unrealistic thoughts about the loss situation. Although they were the least common in our study, that should not be interpreted as if they are less important, because the existing research suggests that high levels of cognitive mourning reactions can lead to depression and anxiety (Worden, 2018). Certain distorted thoughts are more common in the early stages of mourning, but usually, they disappear over time. For the majority of our bereaved sample $(83 \%)$ at least three years had passed since their loss. This may partially explain why cognitive reactions were much less common in our study.

For the effectiveness of therapeutic help, it is important for mental health professionals who work with parentally bereaved clients to develop specific interventions that fit their clients' mourning reaction types so that they can better cope with the loss experience (Christ, 2000). Understanding clients' different reactions about loss by exploring their unrealistic beliefs about the world, and especially about themselves would be essential in the helping process.

\section{Limitations and Suggestions for Future Research}

Our intention was the constitution of loss and no loss groups by controlling all other losses except the parental loss so that we could confidently compare them, but since that reduced the size of the loss group to only two participants, it was not possible to do so. With larger samples, statistical controls or with qualitative in-depth analyses the impact of early parental loss may be more clearly examined.

Our demographic form did not allow identifying who were the multiple losses in the lives of the participants. Future studies examining the impact of loss are 
recommended to use an open-ended format so that they can specify various losses, including loss of domestic animals.

One major limitation was that our data were based on only self-reports, and this may have limited the validity of our findings. Particularly, future researchers who may use qualitative methods may prefer interview-based assessment of adult attachment patterns. Some of the inconsistent findings in the literature on adult attachment may be due to the subjective nature of this measurement especially when compared with observation-based assessment of attachment styles of young children.

We utilized online access to the survey that may have limited a fuller representation of the general student body. First, although internet use among university students is the standard means rather than an exception, we may have excluded some individuals who might feel skeptical about or are uninterested in online surveys. Second, the data collection occurred near to the end of the academic year when students were occupied with assignments, finals as well as music and sports festivals; otherwise we could have more students participating in the study and have achieved more generalizable results.

Generalization of our findings is limited since we studied only a single public university in İstanbul. Replication with different samples is recommended for the establishment of further validity. Majority of our participants happened to have middle SES. However, it was suggested that individuals with low SES may experience parental loss differently and have higher levels of mourning reactions (Morgan, 1982). We could not examine SES differences as there were only eight participants with low SES in our loss group. Future research with larger samples that can be representative of different SES levels may explore the related SES differences.

To understand sample characteristics, we only asked the current romantic relationship status of the participants (whether they were currently in a relationship, not in a current relationship or never had any relationship) and the parent loss and the no parent loss participants seemed to be similar. We only examined their romantic relationship beliefs, but future studies may look into their actual relationship characteristics that may provide better profiles in relation to attachment patterns of young people with and without parental loss.

Because of the limited sample size of our loss group, we could not use multivariate statistics to test the influence of mourning level on the relationship between attachment patterns and dysfunctional romantic relationship beliefs, but studies with larger samples may attempt to use structural analyses and tests of moderation/mediation among multiple variables and can draw more comprehensive pictures.

Dismissing and preoccupied attachment patterns were more common than the secure attachment patterns among our participants. It was surprising not to find secure attachment patterns as the most common predominant attachment pattern in the sample, but ours was not the only one with this finding as another study with a similar population found similar results (Pancaroğlu, 2007). Further studies of normative nature are needed to examine the predominant attachment patterns distribution of Turkish young adults across different samples. 


\section{Authors' Note}

This study was approved by Human Research Ethics Committee of Bogazici University (Approval no. 2017/53).

\section{References}

Abrams, R. (2013). When parents die: Learning to live with the loss of a parent. Routledge.

Ainsworth, M. D. S. (1978). The Bowlby-Ainsworth attachment theory. Behavioral and Brain Sciences, 1(3), 436-438.

Ainsworth, M. D. S. (1979). Attachment as related to mother-infant interaction. Advances in the Study of Behavior, 9, 1-51

Ainsworth, M. D. S., \& Bell, S. M. (1970). Attachment, exploration, and separation: Illustrated by the behavior of one-year-olds in a strange situation. Child Development, 1(41), 49-67

Ainsworth, M. D. S., Blehar, M. C., Waters, E., \& Wall, S. N. (1978). Patterns of attachment: A psychological study of the strange situation. Lawrence Erlbaum Associates.

Akerman, R., \& Statham, J. (2014). Bereavement in childhood: The impact on psychological and educational outcomes and the effectiveness of support services. Child Wellbeing Research Centre and the Institute of Education.

Balcı-Çelik, S. (2006). Yas ölçeği: Geçerlik ve güvenirlik çalışması. Türk Psikolojik Danışma ve Rehberlik Dergisi, 3(25), 105-114.

Banse, R. (2004). Attachment style and marital satisfaction: Evidence for dyadic configuration effects. Journal of Social and Personal Relationships, 21(2), 273-282.

Barner, J., \& Rosenblatt, P. (2008). Giving at a loss: Couple exchange after the death of a parent. Mortality, 13(4), 318-334.

Bartholomew, K., \& Horowitz, L. M. (1991). Attachment styles among young adults: A test of a four-category model. Journal of Personality and Social Psychology, 61(2), 226.

Bartholomew, K., \& Shaver, P. R. (1998). Methods of assessing adult attachment. Attachment Theory and Close Relationships, 2(1), 25-45.

Beck, A. T. (1979). Cognitive therapy and the emotional disorder. Meridian Book.

Beştav, G. (2007). Romantik ilişki doyumu ile cinsiyet, bağlanma stilleri, rasyonel olmayan inançlar ve aşka ilişkin tutumlar arasındaki ilişkilerin incelenmesi. Yayınlanmamış yüksek lisans tezi. Hacettepe Üniversitesi.

Birtchnell, J. (1970). The relationship between attempted suicide, depression and parent death. The British Journal of Psychiatry, 116(532), 307-313

Birtchnell, J. (1972). Early parent death and psychiatric diagnosis. Social Psychiatry, 7(4), 202-210

Bonanno, G. A., \& Kaltman, S. (2001). The varieties of grief experience. Clinical Psychology Review, 21(5), 705-734.

Bowlby, J. (1972). Attachment: Attachment and loss (Vol. 1). Pimlico.

Bowlby, J. (1980). Attachment and loss (Vol. 3). Pimlico. 
Bowlby, J. (1998). Loss: Sadness and depression (No. 3). Random House.

Brassard, A., Shaver, P. R., \& Lussier, Y. (2007). Attachment, sexual experience, and sexual pressure in romantic relationships: A dyadic approach. Personal Relationships, 14(2), 475-494.

Brazelton, T. B., \& Yogman, M. W. (1986). Affective development in infancy. Ablex Publications.

Brennan, K. A., \& Shaver, P. R. (1998). Attachment styles and personality disorders: Their connections to each other and to parental divorce, parental death, and perceptions of parental caregiving. Journal of Personality, 66(5), 835-878.

Canatan, K. (2009). Aile sosyolojisi. Aç1lım Kitap.

Carter, S., \& Sokol, J. (1988). Men who can't love. Penguin Group.

Carver, K. S., Hayslip, B., Gilley, A., \& Watts, J. (2014). Influences on grief among parentally bereaved adults. Journal of Death and Dying, 69(2), 105-116.

Christ, G. H. (2000). Impact of development on children's mourning. Cancer Practice, $8(2), 72-81$.

Collins, N. L., Guichard, A. C., Ford, M. B., \& Feeney, B. C. (2006). Responding to need in intimate relationships: Normative processes and individual differences. In M. Mikulincer \& G. S. Goodman (Eds.), Dynamics of romantic love: Attachment, caregiving, and sex (pp. 149-189). Guilford Press. https://doi.org/10.1177/0265407509360907

Cordell, A. S., \& Thomas, N. (1997). Perinatal loss: Intensity and duration of emotional recovery. Journal of Death and Dying, 35(3), 297-308.

Corr, C., \& Corr, D. (2013). Death and dying, life and living. Wadsworth.

Çevik A. (2000). Yas ve biyo-psikososyal sonuçlar [Poster presentation]. Dokuzuncu Anadolu Psikiyatri Günleri, Edirne, Türkiye.

Dean, J. (1988). Grief and attachment. Journal of Religion and Health, 27(2), 157-165.

DiGiuseppe, R., \& Zee, C. (1986). A rational emotive theory of marital dysfunction and marital therapy. Journal of Rational Emotive Therapy, 4(1), 22-37.

Dyregrov, A. (2006). Çocuk kayıplar ve yas (G. Güvenç, Trans.). Türk Psikologlar Derneği. (Originally published 2000).

Ellis, A. (1957). Rational psychotherapy and individual psychology. Journal of Individual Psychology, 13(1), 38-44.

Ellis, A. (1986). Rational emotive therapy applied to relationships therapy. Journal of Rational Emotive Behavior Therapy, 4(1), 4-21.

Ellis, A. (2003). The nature of disturbed marital interaction. Journal of RationalEmotive \& Cognitive-Behavior Therapy, 21(3), 147-153.

Ellis, R. T., \& Granger, J. M. (2002). African American adults' perceptions of the effects of parental loss during adolescence. Child and Adolescent Social Work Journal, 19(4), 271-284.

Epstein, N., \& Eidelson, R. J. (1981). Unrealistic beliefs of clinical couples: Their relationship to expectations, goals, and satisfaction. American Journal of Family Therapy, 9(4), 13-22

Erdman, P., \& Caffery, T. (Eds.). (2013). Attachment and family systems: Conceptual, empirical and therapeutic relatedness. Routledge.

Erikson E. H. (1982). The life cycle completed. Norton.

Erikson, E. H. (1994). Identity: Youth and crisis. Faber and Faber. 
Feeney, B. C., \& Collins, N. L. (2004). Interpersonal safe haven and secure base caregiving processes in adulthood. Guilford Press.

Feeney, J. A., \& Noller, P. (1990). Attachment style as a predictor of adult romantic relationships. Journal of Personality and Social Psychology, 58(2), 281.

Field, N. P. (2006). Unresolved grief and continuing bonds: An attachment perspective. Death Studies, 30(8), 739-756.

Fincham, F. D., \& Bradbury, T. N. (1987). The impact of attributions in marriage: A longitudinal analysis. Journal of Personality and Social Psychology, 53(3), 510.

Fulton, R., \& Markusen, E. (1971). Childhood bereavement and behavior disorders: A critical review. Journal of Death and Dying, 2(2), 107-117.

George, C., Kaplan, N., \& Main, M. (1985). Adult attachment interview protocol. Unpublished manuscript. University of California.

Gizir, C. A. (2012). İlişki inançları ölçeği’nin uyarlanması: Geçerlik ve güvenirlik çalışmaları. Mersin Üniversitesi Eğitim Fakültesi Dergisi, 8(2), 37-45.

Griffin, D. W., \& Bartholomew, K. (1994). Models of the self and other: Fundamental dimensions underlying measures of adult attachment. Journal of Personality and Social Psychology, 67(3), 430.

Hamamc1, Z. (2007). Dysfunctional relationship beliefs in parent-late adolescent relationship and conflict resolution behaviors. College Student Journal, 41(1), 122-138.

Hammond, J. R., \& Fletcher, G. J. (1991). Attachment styles and relationship satisfaction in the development of close relationships. New Zealand Journal of Psychology, 20(1), 56.

Harvey, O. J., Hunt, D. E., \& Schroder, H. M. (1961). Conceptual systems and personality organization. Wiley.

Hatfield, E., \& Rapson, R.L. (1993). Love, sex and intimacy: Their psychology, biology and history. Harper Collins College Publishers.

Hayslip Jr, B., Pruett, J. H., \& Caballero, D. M. (2015). The "how" and "when" of parental loss in adulthood: Effects on grief and adjustment. Journal of Death and Dying, 71(1), 3-18.

Hazan, C., \& Shaver, P. (1987). Romantic love conceptualized as an attachment process. Journal of Personality and Social Psychology, 52(3), 511-524.

Hepworth, J., Ryder, R. G., \& Dreyer, A. S. (1984). The effects of parental loss on the formation of intimate relationships. Journal of Marital and Family Therapy, 10(1), 73-82.

Illene, C. N. (2000). Beyond broken bonds and broken hearts: The bonding of theories of attachment and grief Developmental Review, 20(1), 514-538. https://doi.org/10.1006/drev.2000.0510

Jankowiak, W. R., \& Fischer, E. F. (1992). A cross-cultural perspective on romantic love. Ethnology, 31(1), 149-155. https://doi.org/10.2307/3773618

Jones, S., \& Martini, M. (2021). Sense of self, depression and adaption to grief, in emerging adults who suffered parental loss. Current Psychology. https://doi.org/10.1007/s12144-021-01843-z 
Kaya, Y., \& Öz, F. (2020). Ergenlerin benlik algis1 üzerinde algılanan ebeveyn tutumlarının ve bağlanma stillerinin rolü: Bir yapısal eşitlik modellemesi. Psikiyatri Hemşireliği Dergisi, 11(2), 106-114.

Kendler, K. S., Neale, M. C., Kessler, R. C., Heath, A. C., \& Eaves, L. J. (1992). Childhood parental loss and adult psychopathology in women: A twin study perspective. Archives of General Psychiatry, 49(2), 109-116. https://doi:10.1001/archpsyc.1992.01820020029004

Kernberg, O. F. (1998). Love relations: Normality and pathology. Yale University Press.

Kıvılcım, M., \& Doğan, D. G. (2014). Çocuk ve ölüm. Turgut Özal Tıp Merkezi Dergisi, 21(2), 81-84.

Kübler-Ross, E., Kessler, D., \& Shriver, M. (2014). On grief and grieving: Finding the meaning of grief through the five stages of loss. Scribner.

Levy, K. N., Ellison, W. D., Scott, L. N., \& Bernecker, S. L. (2011). Attachment style. Journal of Clinical Psychology, 67(2), 193-203.

Lewis, E., (1979). Two hidden predisposing factors in child abuse. Child Abuse and Neglect, 3, 327-330.

Li, J. B., Delvecchio, E., Lis, A., Nie, Y. G., \& Di Riso, D. (2015). Parental attachment, self-control, and depressive symptoms in Chinese and Italian adolescents: Test of a mediation model. Journal of Adolescence, 43, 159-170.

Lim, Y., \& Lee, O. (2017). Relationships between parental maltreatment and adolescents' school adjustment: Mediating roles of self-esteem and peer attachment. Journal of Child and Family Studies, 26(2), 393-404.

Luecken, L. J. (2000). Attachment and loss experiences during childhood are associated with adult hostility, depression, and social support. Journal of Psychosomatic Research, 49(1), 85-91.

Lussier, Y., Sabourin, S., \& Turgeon, C. (1997). Coping strategies as moderators of the relationship between attachment and marital adjustment. Journal of Social and Personal Relationships, 14(6), 777-791.

Mikulincer, M., Shaver, P. R., Gillath, O., \& Nitzberg, R. E. (2005). Attachment, caregiving, and altruism: Boosting attachment security increases compassion and helping. Journal of Personality and Social Psychology, 89(2), 817-839.

Morgan, J. N. (1982). The redistribution of income by families and institutions and emergency help patterns. Five Thousand American Families, 10(1), 1-59.

Neimeyer, R. A., Harris, D. L., Winokuer, H. R., \& Thornton, G. F. (2011). Grief and bereavement in contemporary society: Bridging research and practice. Routledge.

Padesky, C. A. (1994). Schema change processes in cognitive therapy. Clinical Psychology \& Psychotherapy, 1(5), 267-278.

Pancaroğlu, S. (2007). The relationships of attachment styles and conflict behaviors among male and female university students. Unpublished master's thesis. Middle East Technical University.

Parkes, C. M., \& Prigerson, H. G. (2013). Bereavement: Studies of grief in adult life. Penguin Books. https://doi.org/10.1192/S0007125000141029

Parkes, C. M., \& Weiss, R. S. (1983). Recovery from bereavement. Basic Books. https://doi.org/10.1080/0742-969X.1985.11882532 
Pascuzzo, K., Cyr, C., \& Moss, E. (2013). Longitudinal association between adolescent attachment, adult romantic attachment, and emotion regulation strategies. Attachment \& Human Development, 15(1), 83-103.

Pollock, G. H. (1961). Mourning and adaptation. International Journal of PsychoAnalysis, 42, 341-361.

Popper, M., \& Amit, K. (2009). Influence of attachment style on major psychological capacities to lead. The Journal of Genetic Psychology, 170(3), 244-267.

Reid J.K., \& Dixon, W.A. (2000). The relationships among grief experience, problemsolving appraisal, and depression: An exploratory study. Journal of Personal and Interpersonal Loss, 5(4), 77-93.

Rogers, J. E. (2011). The art of grief: The use of expressive arts in a grief support group. Routledge. https://doi.org/10.1080/07481180903559352

Romans, J. S., \& DeBord, J. (1995). Development of the relationship beliefs questionnaire. Psychological Reports, 76, 1248-1251.

Rosenblatt, P. C., \& Wallace, B. R. (2013). African American grief. Taylor and Francis.

Rubin, S., \& Yasien-Esmael. H. (2004). Loss and bereavement among Israel's Muslims: Acceptance of God's will, grief, and relationship to the deceased. The Journal of Death and Dying, 49, 149-162.

Scharlach, A. E. (1991). Factors associated with filial grief following the death of an elderly parent. American Journal of Orthopsychiatry, 61(2), 307-313.

Schmitt, D. P., Alcalay, L., Allensworth, M., Allik, J., Ault, L., Austers, I., Bennett, K. L., Bianchi, G., Boholst, F., Cunen, M. A., Braeckman, J., Brainerd, E. G., Caral, L. G., Caron, G., Casullo, M. M., Cunningham, M., Daibo, I., De Backer, C., De Souza, E., ZupanÈiÈ, A. (2004). Patterns and universals of adult romantic attachment across 62 cultural regions: Are models of self and of other pancultural constructs? Journal of Cross-Cultural Psychology, 35(4), 367-402. https://doi.org/10.1177/0022022104266105

Senchak, M., \& Leonard, K. E. (1992). Attachment styles and marital adjustment among newlywed couples. Journal of Social and Personal Relationships, 9(1), 51-64.

Shear, K., \& Shair, H. (2005). Attachment, loss, and complicated grief. The Journal of the International Society for Developmental Psychobiology, 47(3), 253-267.

Simpson, J. A. (1990). Influence of attachment styles on romantic relationships. Journal of Personality and Social Psychology, 59(5), 971.

Stackert, R. A., \& Bursik, K. (2003). Why am I unsatisfied? Adult attachment style, gendered irrational relationship beliefs, and young adult romantic relationship satisfaction. Personality and Individual Differences, 34(8), 1419-1429.

Stroebe, M. S., Hansson, R. O., Schut, H. E., \& Stroebe, W. E. (2008). Handbook of bereavement research and practice: Advances in theory and intervention. American Psychological Association. https://doi.org/10.1037/14498-000

Stroebe, M., \& Schut, H. (2005). To continue or relinquish bonds: A review of consequences for the bereaved. Death Studies, 29(6), 477-494.

Stroebe, M., Schut, H., \& Stroebe, W. (2005). Attachment in coping with bereavement: A theoretical integration. Review of General Psychology, 9(1), 48.

Sullivan, B. F., \& Schwebel, A. I. (1995). Relationship beliefs and expectations of satisfaction in marital relationships: Implications for family practitioners. The Family Journal, 3(4), 298-305. 
Sümer, N., \& Güngör, D. (1999). Yetişkin bağlanma stilleri ölçeklerinin Türk örneklemi üzerinde psikometrik değerlendirmesi ve kültürlerarası bir karşılaştırma. Türk Psikoloji Dergisi, 14(43), 71-106.

Şenkaya-Dildar, F. (2000). Çocuklarda posttravmatik stres bozukluğu [Poster presentation]. Dokuzuncu Anadolu Psikiyatri Günleri, Edirne, Türkiye.

Şentürk, Ü. (2006). Parçalanmış aile çocuk ilişkisinin sebep olduğu sosyal problemler. Yayınlanmamış doktora tezi. İnönü Üniversitesi.

Taylor, G. J., Bagby, R. M., \& Parker, J. D. (1999). Disorders of affect regulation: Alexithymia in medical and psychiatric illness. Cambridge University Press.

Tokuş, T. (2014) Illişki modellerinde bağlanma stilleri ve utancın rolü. Yayınlanmamış yüksek lisans tezi. Bilgi Üniversitesi.

Tracy, J. L., Shaver, P. R., Albino, A. W., \& Cooper, M. L. (2003). Attachment styles and adolescent sexuality. Erlbaum.

Tuazon, V. E., \& Gressard, C. F. (2021). Developmental impact of early parental death: Sustaining posttraumatic growth throughout the lifespan. Journal of Death and Dying. https://doi.org/10.1177/00302228211024466

Waldinger, R. J., Vaillant, G. E., \& Orav, E. J. (2007). Childhood sibling relationships as a predictor of major depression in adulthood: A 30-year prospective study. American Journal of Psychiatry, 164(6), 949-954.

Wallach, V., \& Caulfield, R. (1998). Attachment and at-risk infants: Theoretical perspectives and clinical implications. Early Childhood Education Journal, 26(2), 125-129.

Walter, C. A., \& McCoyd, J. L. (2015). Grief and loss across the lifespan: A biopsychosocial perspective. Springer Publishing Company.

Waters, E., Merrick, S., Treboux, D., Crowell, J., \& Albersheim, L. (2000). Attachment security in infancy and early adulthood: A twenty-year longitudinal study. Child Development, 71, 684-689.

Wayment, H. A., \& Vierthaler, J. (2002). Attachment style and bereavement reactions. Journal of Loss \& Trauma, 7(2), 129-149.

Wearden, A. J., Lamberton, N., Crook, N., \& Walsh, V. (2005). Adult attachment, alexithymia, and symptom reporting: An extension to the four category model of attachment. Journal of Psychosomatic Research, 58(3), 279-288

Whisman, M. A., \& Allan, L. E. (1996). Attachment and social cognition theories of romantic relationships: Convergent or complementary perspectives? Journal of Social and Personal Relationships, 13(2), 263-278.

Widick, C., Parker, C. A., \& Knefelkamp, L. (1978). Erik Erikson and psychosocial development. New Directions for Student Services, 4, 1-17

Widom, C. S., Czaja, S. J., Kozakowski, S. S., \& Chauhan, P. (2018). Does adult attachment style mediate the relationship between childhood maltreatment and mental and physical health outcomes? Child Abuse \& Neglect, 76, 533-545.

Williams, B., Ospina, J. P., Jalilianhasanpour, R., Fricchione, G. L., \& Perez, D. L. (2019). Fearful attachment linked to childhood abuse, alexithymia, and depression in motor functional neurological disorders. The Journal of Neuropsychiatry and Clinical Neurosciences, 31(1), 65-69. 
Willis, C. A. (2002). The grieving process in children: Strategies for understanding, educating, and reconciling children's perceptions of death. Early Childhood Education Journal, 29(4), 221-226.

Worden, J. W. (2018). Grief counseling and grief therapy: A handbook for the mental health practitioner. New Springer Publishing Company.

Yárnoz-Yaben, S. (2010). Attachment style and adjustment to divorce. The Spanish Journal of Psychology, 13(1), 210-219.

\section{Erken Ebeveyn Kaybı Olan ve Olmayan Genç Yetişkinlerde Bağlanma Örüntüleri, Yas Tepkileri ve İșlevsel Olmayan Romantik İlișki İnançları}

$\ddot{\mathbf{O z}}$

Erken ebeveyn kaybı yaşantısıyla ilintili olarak genç yetişkinlerin bağlanma örüntüleri, yas tepkileri ve islevsel olmayan romantik iliski inançlart incelenmistir. Katılımcllar İstanbul'daki bir devlet üniversitesine kayıtlı 423 ögrenciyi kapsamıştır. Veri toplamada çevrimiçi bir tarama paketi kullanılmıştır. Çözümlemeler bağlanma örüntülerinin kayıp durumuna göre değișmediğini göstermistir. Erken ebeveyn kaybı grubunda, kayıtsı bağlanma örüntüsü ile işlevsel olmayan romantik ilişki inançlarl; kayıpsız grupta ise, saplantılı bağlanma örüntüsü ile işlevsel olmayan romantik ilişki inançlarl olumlu ilişkide bulunmuştur. Kayıtsız bağlanma örüntüsü olan ve fazla yas tepkisi gösteren katılımclların ișlevsel olmayan romantik iliski inançlarının daha fazla olduğu bulunmuştur. Davranışsal ve bedensel tiplerin en yaygın; duygusal ve bilişsel tiplerin ise en nadir yas tepkileri olduğu görülmüştür.

Anahtar sözcükler: Erken ebeveyn kaybı, genç yetişkinler, bağlanma örüntüleri, yas tepkileri, ișlevsel olmayan romantik ilişki inançları 